\title{
Patterns of mollusc distribution in mangroves from the São Marcos Bay, coast of Maranhão State, Brazil
}

\author{
Carlos A. L. RODRIGUES ${ }^{1}$, Rannyele P. RIBEIRO ${ }^{1,2, *}$, Nayara B. SANTOS ${ }^{1}$; Zafira S. ALMEIDA ${ }^{1}$ \\ Universidade Estadual do Maranhão, Departamento de Química e Biologia, Avenida Lourenço Vieira da Silva, S/N, Tirirical, São Luís, Maranhão, Brazil. \\ ${ }^{2}$ Universidade Federal do Rio de Janeiro, Núcleo em Ecologia e Desenvolvimento Sócio-ambiental de Macaé. Avenida São José do Barreto 764, São José do Barreto, Macaé, Rio
} de Janeiro, Brazil.

*Correspondig author: rannyele.passos@gmail.com

\begin{abstract}
The diversity and distribution of molluscs from the Amazon Coast of Maranhão State, Brazil, are poorly understood. The aim of this study was to investigate how molluscs in two mangrove creeks (Buenos Aires and Tronco) at the São Marcos Bay, coast of the Maranhão State, respond to spatial and temporal variations in the environment. Sampling was performed in the intertidal area along three zones established using a straight line transect of $100 \mathrm{~m}$. Abiotic variables of water and sediment were measured at each creek. We found 5,912 specimens belonging to 23 species and 15 families of epifaunal and infaunal molluscs. The patterns of their distribution in the two creeks were different. Salinity, dissolved oxygen, and rainfall were the main variables that affected the temporal distribution of molluscs. We found low species richness in the overall mollusc composition. Diversity in the Buenos Aires Creek was lower than that observed in the Tronco Creek, possibly because of activities of a port located in proximity to the former. The spatial distribution of molluscs along the zones followed an abundance and diversity gradient, mainly influenced by exposure time during low tide. Port activities may influence the patterns of mollusc distribution in the surrounding mangroves, and we thus highlight the importance of management and monitoring of these areas.
\end{abstract}

KEYWORDS: benthic fauna, diversity, Littoraria, Melampus, salt creek.

\section{Padrões de distribuição de moluscos em manguezais da Baía de São Marcos, costa do Estado do Maranhão, Brasil}

\section{RESUMO}

A diversidade e distribuição de moluscos na Costa Amazônica do Estado do Maranhão, Brasil, são pobremente conhecidas. O objetivo deste estudo foi investigar como os moluscos em dois igarapés de manguezal (Buenos Aires e Tronco) na Baía de São Marcos, costa do Estado do Maranhão, respondem a variaçóes espaciais e temporais no ambiente. A amostragem foi conduzida no entre-marés ao longo de três zonas estabelecidas a partir de um transecto em linha reta de $100 \mathrm{~m}$. As variáveis abióticas de água e sedimento foram medidas para cada igarapé. Foram contabilizados 5.912 espécimes pertencentes a 23 espécies e 15 famílias na epifauna e endofauna. Os padrōes de distribuição de moluscos foram distintos entre os dois igarapés. Salinidade, oxigênio dissolvido e precipitaçâao foram as principais variáveis que influenciaram a distribuição temporal dos moluscos. Observou-se baixa riqueza de espécies na composição geral de moluscos. A diversidade no igarapé Buenos Aires foi menor do que a observada no igarapé Tronco, possivelmente por causa das atividades portuárias nas proximidades do primeiro. A distribuição espacial vertical de moluscos ao longo das zonas seguiu um gradiente de abundância e diversidade influenciado principalmente pelo tempo de exposição durante a maré baixa. As atividades portuárias podem estar influenciando os padróes de distribuição de moluscos nos manguezais do entorno, portanto destacamos a importância do manejo e monitoramento dessas áreas.

PALAVRAS-CHAVE: fauna bêntica, diversidade, Littoraria, Melampus, igarapé salino. 


\section{INTRODUCTION}

Mangroves are coastal forest formations in tropical and subtropical sheltered areas (Menezes et al. 2008). They are transitional ecosystems between the terrestrial and aquatic environments that have high productivity, ecological importance, and are recognized for their role reproduction and as a nursery for many vertebrates and invertebrates (Alongi 2002; Marquéz and Jimenéz 2002; Gomes et al. 2013). Mangroves are an ideal landscape for the sustainable management of a wide variety of species, because they function as a quiet area with shallow bottom (Marquéz and Jimenéz 2002).

The mangroves on the Brazilian coast are distributed from the states of Amapá to Santa Catarina, covering an area of approximately 13,400 km² (Spalding et al. 1997; SouzaFilho 2005; Menezes et al. 2008). In Brazil, the major tract of mangroves is in the state of Maranhão (Correia and Sovierzoski 2005), representing most of the Brazilian Amazon Coast, and covers an area of about $5,414.31 \mathrm{~km}^{2}$ (Souza-Filho, 2005).

In Maranhão, the knowledge about diversity of marine benthic invertebrates remains limited (Oliveira and Mochel 1999; Ribeiro and Almeida 2014; Sousa et al. 2015). Studies on marine benthic molluscs from the Brazilian Amazon Coast have mostly been undertaken in the state of Pará (e.g. Aviz et al. 2012; Melo et al. 2013; Morais and Lee 2014).

The Amazon River might act as a barrier to the geographical distribution of marine organisms (Greenfield 1989; Floeter and Gasparini 2000; Luiz et al. 2012), and hence, it greatly influences the structural and functional ecosystem patterns of these mangroves (Amaral et al. 2014). A high abundance of benthic organisms can be found in these mangroves, including molluscs, which can inhabit a variety of environments and are one of the largest and richest invertebrate phyla in number of species (Ardila et al. 2002). They perform several significant ecologically functions, including structuring habitats for other benthic organisms, purifying water, and serving as a source of food for many organisms (Gazeau et al. 2013).

The distribution of benthic organisms can be influenced by environmental variables such as salinity, dissolved oxygen, conductivity, and grain size, which affect the functioning of communities (Hall 1994; Barroso and Matthews-Cascon 2009; Santi and Tavares 2009; Rezende et al. 2014). Hydrodynamic patterns regulated by seasonal phenomena such as rainfall can cause major changes in the distribution of organisms, both spatially and temporally (Soares-Gomes and Pires-Vanin 2003; Odum and Barret 2007). In intertidal communities, the zonation of organisms can follow a physiological stress gradient due to environmental conditions such as varying tides, sediment properties, submergence, and duration of exposure (Peterson 1991; Dittmann 2000; Tanaka and Maia 2006; Maia and Tanaka 2007).

In this sense, because there are two distinct seasons in the Amazon Coast, we expected that in the rainy season, the increase in water volume would reduce the impact of pollutants that might be present, thus increasing the abundance of organisms. We also anticipated that the richness and diversity in perturbed areas should be lower than those in protected areas. Furthermore, we expected that the intertidal organisms would be distributed following a zonation pattern resulting from different conditions caused by tidal variations. The aim of this study was to investigate how molluscs in two mangrove creeks (Buenos Aires and Tronco) at the São Marcos Bay, coast of the Maranhão State respond to spatial and temporal variations in the environment.

\section{MATERIALS AND METHODS}

\section{Study area}

São Marcos Bay is an active estuary dominated by mangroves; spread approximately $100 \mathrm{~km}$ in length with the rivers Grajaú, Mearim, and Pindaré draining into it. It is located on the coast of Maranhão, where the climate is characterized by two main seasons: the dry season (from June to November, with minimum temperature of $22^{\circ} \mathrm{C}$, and up to $200 \mathrm{~mm}$ of rainfall) and the rainy season (from December to May, with minimum temperature of $20^{\circ} \mathrm{C}$, and rainfall above 1,500 mm) (Silva et al. 2009; Núcleo Geoambiental 2012). In this bay, the macrotidal regime reaches up to $7 \mathrm{~m}$ with tidal currents up to $2 \mathrm{~m}$ (Pereira and Harari 1995).

The study sites are two mangrove creeks in the São Marcos Bay (Figure 1A). The first, the Buenos Aires Creek, is located near the port and industrial region of São Luís ( $2^{\circ} 35^{\prime} 57.7^{\prime \prime}$ S; $\left.44^{\circ} 21^{\prime} 09.4^{\prime \prime} \mathrm{W}\right)$. This 40-m-wide creek with a depth of about $5 \mathrm{~m}$ at the mouth is indirectly influenced by the Port of Itaqui, one of the main ports of Brazil. The second site, the Tronco Creek, is located at the Caranguejos Island ( $2^{\circ} 49^{\prime}$ 56.24" S; $\left.44^{\circ} 29^{\prime} 41.92^{\prime \prime} \mathrm{W}\right)$, is a 300-m-wide protected area with a depth of approximately $20 \mathrm{~m}$ at the mouth.

\section{Sampling}

Sampling was conducted in April, August, and October 2010; January, March, September, and December 2011; and March, June, and September 2012. The molluscs among the epifauna and infauna were collected from a sampling site (a reach) that was selected at random at each mangrove creek. We considered epifauna as the organisms of the sediment surface and infauna as the organisms within the sediment. We collected the samples along a straight line transect of 100 $\mathrm{m}$, perpendicular to the water line in the intertidal mangrovevegetated area. The transect was subdivided into three zones 

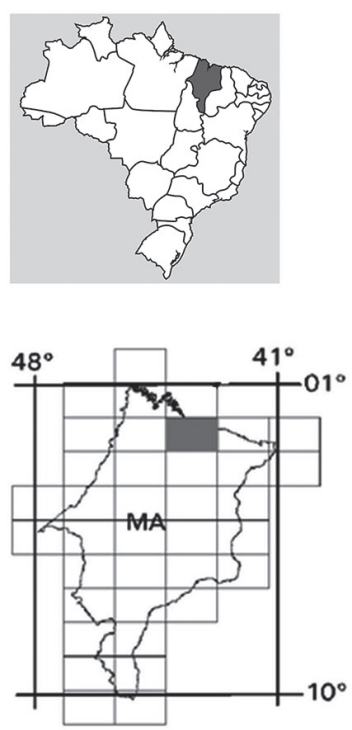

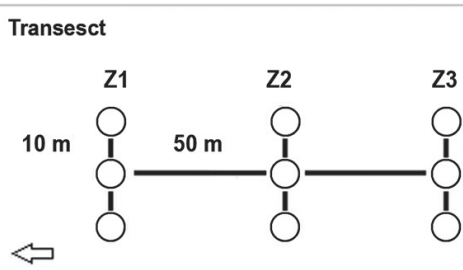

Infralittoral

B

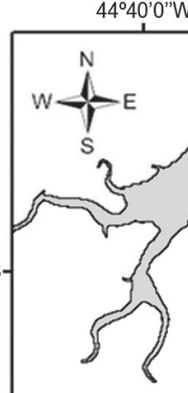

$44^{\circ} 40^{\prime} 0^{\prime \prime} \mathrm{V}$

$44^{\circ} 20^{\prime} 0^{\prime \prime} \mathrm{W}$

$-2^{\circ} 20^{\prime} 0^{\prime \prime} \mathrm{S}$

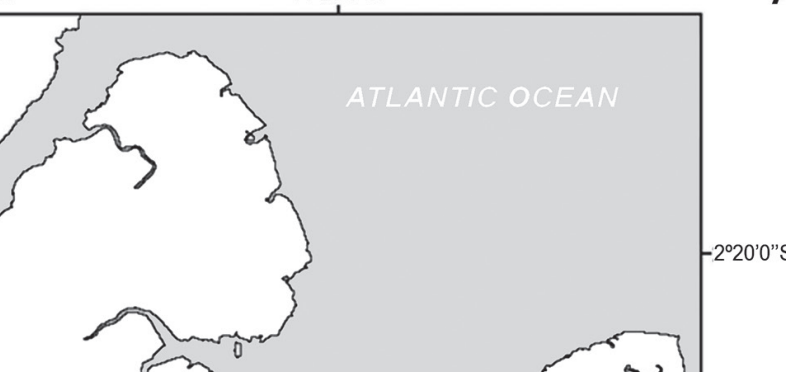

$2^{\circ} 40^{\prime} 0^{\prime \prime}$
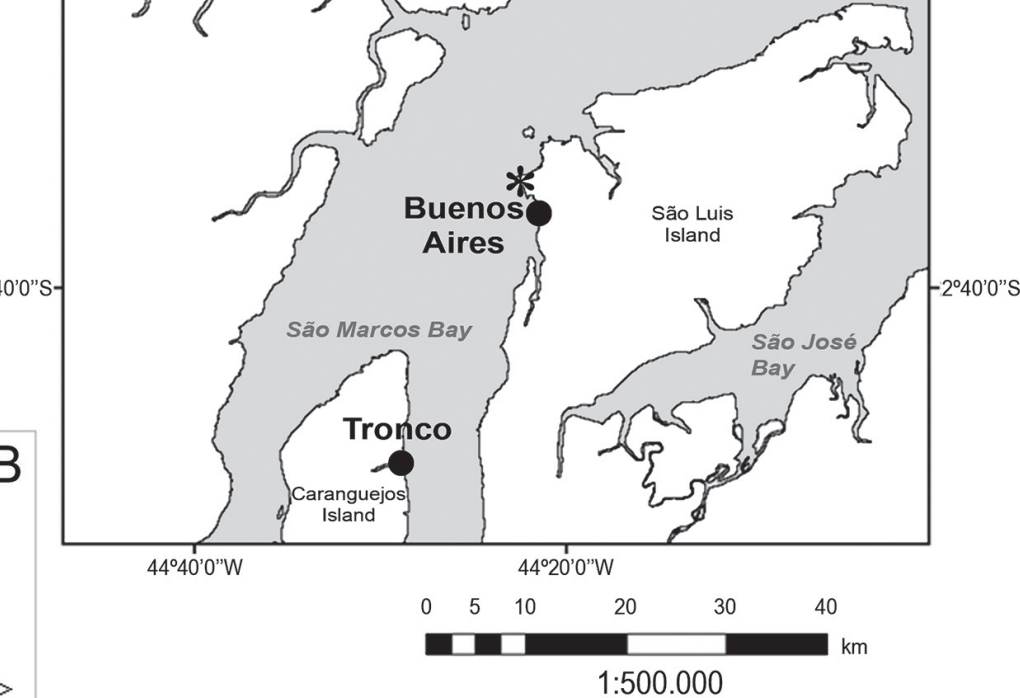

$1: 500.000$

Figure 1. Location of the study area. (A) Buenos Aires Creek, São Luís Island, and Tronco Creek, Caranguejos' Island, São Marcos Bay, Maranhão, Brazil. (B) Representation of sampling transects. $\left(^{*}\right)$ Location of Port of Itaqui.

according to the distance from the beginning of the intertidal zone: Zone 1 at $0 \mathrm{~m}$, Zone 2 at $50 \mathrm{~m}$ and Zone 3 at $100 \mathrm{~m}$.

The molluscs of the epifauna and infauna were collected in a reach randomly selected at each mangrove creek. We considered epifauna as the organisms of the sediment surface and infauna as the organisms within the sediment (Tagliapietra and Sigovini 2010). We collected the samples along a vertical transect of $100 \mathrm{~m}$, perpendicular to the water line in the intertidal mangrove-vegetated area. The transect was subdivided into three zones according to the distance from the beginning of the intertidal zone: Zone 1 at $0 \mathrm{~m}$, Zone 2 at $50 \mathrm{~m}$ and Zone 3 at $100 \mathrm{~m}$ (Figure 1B).

During low tide, we took three sediment samples (infauna) at each zone, one on the transect main line and the other two, $10 \mathrm{~m}$ away from the transect main line (Figure 1B). The collection equipment used was a corer proposed by Mochel (1986): $1 \mathrm{~m}$ long, $10 \mathrm{~cm}$ in diameter with serrated lower edges, and the sediment layer depth was $20 \mathrm{~cm}$. The sediment samples collected were fixed in $4 \%$ formaldehyde for at least
24 hours, after washed in superposed sieves of $0.5 \mathrm{~mm}$, $1.0 \mathrm{~mm}$, and $2.0 \mathrm{~mm}$ mesh and the material retained were preserved in $70 \%$ ethanol. The material was then screened and the specimens were separated and identified at the lowest possible taxonomic level.

We sampled for epifauna by means of a scanning during 10 minutes (Beasley et al., 2005) in a circular area about $28 \mathrm{~m}^{2}$ around the locations where we sampled for the infauna. The molluscs found on roots, trunks and sediment surface were counted and identified in the field, at the family level. We captured at least 10 specimens of each family for taxonomic identification; they were fixed in $4 \%$ formaldehyde and preserved in $70 \%$ ethanol. Most of the collected specimens were identified in the Laboratório de Pesca e Ecologia Aquática (LabPEA) of the Universidade Estadual do Maranhão (UEMA). Some specimens were sent to Laboratório de Malacologia, Museu de Zoologia da Universidade de São Paulo (MZUSP). We deposited some of the specimens collected at the MZUSP, whereas others were retained at the 
LabPEA zoological collection for further studies, and will be subsequently deposited in appropriate reference collections.

Abiotic variables of water and grain size analysis were performed to evaluate their influence on the distribution of molluscs. A single sample of water was collected at each creek every month (only until June 2012) to measure the $\mathrm{pH}$, temperature, salinity and dissolved oxygen. These variables were measured using the multiparameter meter Hanna HI9828. A single sediment sample was collected at each creek in April 2010 to perform grain analysis in Laboratório de Física de Solos, UEMA. Data on the total rainfall for the years 20102012 were obtained from the Laboratório de Meteorologia, Núcleo Geoambiental (NUGEO) of the UEMA.

\section{Data analysis}

The distribution of molluscs was analyzed separately for epifauna and infauna owing to their different characteristics and the sampling methods employed. We considered the abiotic variables of water and rainfall to assess the temporal distribution of molluscs. We calculated the mean and standard deviation of the water variables of each creek. The abundance of molluscs in each month was compared with the rainfall records from north of the Maranhão State for the month of sampling and for the month before it using graphics.

To assess their spatial distribution in the creeks, we calculated the community descriptors and undertook a non-metric multidimensional scaling (NMDS) analysis. The community descriptors, namely, abundance $(\mathrm{N})$, richness $(\mathrm{S})$, diversity index of Shannon $\left(\mathrm{H}^{\prime}\right)$, and evenness of Pielou (J') for each zone within each of the studied mangrove creek were determined. We grouped the abundance data of molluscs by creeks and zones, and this data was then square root transformed to stabilize variances. We then assessed the similarities (Bray-Curtis) in the composition of molluscs among the zones and creeks using NMDS. The contribution of each taxon to the similarity and dissimilarity between zones and creeks was verified by a SIMPER analysis (percentage of similarity). We performed these analyses using the statistical program PRIMER 6.0 (Clarke and Warwick 2001; Clarke and Gorley 2006).

\section{RESULTS}

\section{Mollusc composition}

We counted a total of 5,912 epifaunal molluscs belonging to the following species: Littoraria angulifera, Littoraria flava, Melampus coffea e Thaisella coronata (Table 1). The most abundant family was Ellobiidae (Melampus coffea), with 206 individuals recorded in the Buenos Aires Creek, and 2887 in the Tronco Creek. Melampus coffea was found on the muddy sediment in all zones of the studied mangroves. We usually saw some specimens of family Littorinidae under the branches and leaves of the mangrove trees.

We found 126 individuals belonging to 21 species, 15 families and two classes of molluscs among the infauna. Of the 15 families recorded, the family Lucinidae was registered only in the Buenos Aires Creek.

\section{Temporal variation}

In general, the abundance of both epifaunal (Figure 2A) and infaunal (Figure 2B) molluscs was higher in the rainy months. Both creeks also responded to an increase in rainfall. The number of infauna molluscs in periods of low rainfall (dry) was lower (0-3 specimens) than in the rainy season (15-26 specimens), excluding the September 2012 event. Thus, the distribution of molluscs shows an oscillatory pattern between the periods considered dry (less abundant) and rainy (greater abundance).

The mean values of the environmental variables that were measured for water were similar in the creeks (Table 2). Salinity varied greatly in both creeks, especially in Buenos

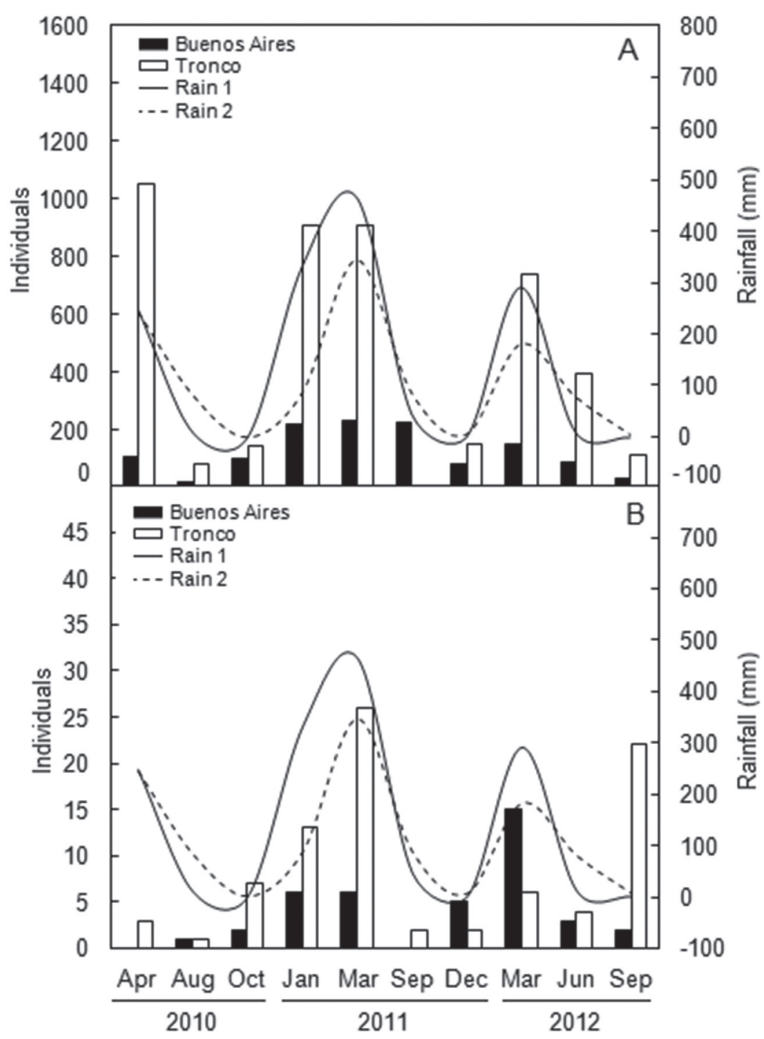

Figure 2. Mollusc abundance in the sampling months in the two studied mangrove creeks and rainfall average values of the Maranhão. (A) Epifauna. (B) Infauna. Rain 1: rainfall in the sampling month. Rain 2: rainfall in the previous month to the sampling. 
Aires Creek, where the standard deviation was higher (Table 2). Dissolved oxygen also presents a high variation of almost 5 $\mathrm{mg} \mathrm{L}^{-1}$ in the Buenos Aires Creek and $6 \mathrm{mg} \mathrm{L}^{-1}$ in the Tronco Creek (Table 2).

\section{Spatial variation}

Overall, the abundance, diversity, and evenness of epifaunal molluscs were higher at the Tronco Creek. The Zone 1 of the Tronco Creek exhibited the highest values for both diversity (0.932) and evenness (0.849), and a gradient in the diversity $(0.932-0.023)$ and evenness $(0.849-0.034)$ from
Zone 1 to Zone 3 (Table 3). This diversity gradient was not observed in the Buenos Aires Creek.

The abundance, diversity, and evenness of infauna were higher than that of epifauna. In the Buenos Aires Creek, the highest diversity was 1.619 in Zone 2 and the highest evenness was 0.969 in Zone 1 (Table 3). We observed that the Zone 1 of the Tronco Creek was not representative of the number of specimens or the species richness, however it exhibited high diversity (1.475) and evenness (0.916) (Table 3). The same pattern of decreasing diversity found in epifauna was observed in the infauna of both the creeks.

Table 1. List of mollusc species of epifauna and infauna found in mangroves Buenos Aires and Tronco.

\begin{tabular}{|c|c|c|c|c|c|}
\hline Habitat & Family & Species & $\mathrm{BA}$ & $\mathrm{T}$ & Total \\
\hline \multirow[t]{4}{*}{ Epifauna* } & Ellobiidae & Melampus coffea (Linnaeus, 1758) & 206 & 2887 & 3093 \\
\hline & Littorinidae & $\begin{array}{l}\text { Littoraria angulifera (Lamarck, 1822) } \\
\text { Littoraria flava (King 1832) }\end{array}$ & 948 & 911 & 1859 \\
\hline & Lucinidae & Phacoides pectinatus (Gmelin, 1791) & 29 & 0 & 29 \\
\hline & Muricidae & Thaisella coronata (Lamarck, 1816) & 90 & 715 & 805 \\
\hline \multirow[t]{21}{*}{ Infauna } & Barleeidae & Barleeia sp. & 9 & 0 & 9 \\
\hline & Columbellidae & Parvanachis obesa (C. B. Adams, 1845) & 0 & 5 & 5 \\
\hline & Cylichnidae & Cylichna sp. & 0 & 1 & 1 \\
\hline & Cyrenoididae & Cyrenoida sp. & 0 & 8 & 8 \\
\hline & Ellobiidae & Melampus coffea (Linnaeus 1758) & 15 & 60 & 75 \\
\hline & & Blauneria heteroclita (Montagu, 1808) & 2 & 0 & 2 \\
\hline & & Ellobium dominicense (Férussac, 1821) & 0 & 1 & 1 \\
\hline & Hidrobiidae & Heleobia sp. & 1 & 0 & 1 \\
\hline & Littorinidae & Littoraria angulifera (Lamarck, 1822) & 2 & 1 & 3 \\
\hline & & Littoraria flava (King 1832) & 1 & 1 & 2 \\
\hline & & Littoraria sp. & 1 & 0 & 1 \\
\hline & Lucinidae & Phacoides pectinatus (Gmelin, 1791) & 2 & 0 & 2 \\
\hline & Muricidae & Stramonita brasiliensis Claremont \& D. G. Reid, 2011 & 1 & 1 & 2 \\
\hline & Nassaridae & Nassarius sp. & 0 & 1 & 1 \\
\hline & Naticidae & Natica marochiensis (Gmelin, 1791) & 0 & 1 & 1 \\
\hline & Pyramidellidae & Sayella sp. & 0 & 1 & 1 \\
\hline & & Miralda sp. & 0 & 4 & 4 \\
\hline & & Odostomia sp. & 2 & 0 & 2 \\
\hline & Risoidae & Benthonela sp. & 3 & 0 & 3 \\
\hline & Tellinidae & Macoma constricta (Bruguière, 1792) & 1 & 0 & 1 \\
\hline & Vitrinellidae & Cyclostremiscus sp. & 0 & 1 & 1 \\
\hline
\end{tabular}

*Number of individuals by family level. 
Table 2. Abiotic variables obtained of Buenos Aires Creek and Tronco Creek during the period from April 2010 to June 2012: pH, temperature (Temp.), salinity (Sal.), oxygen dissolved (D0), with variable mean and standard deviation (SD).

\begin{tabular}{|c|c|c|c|c|c|c|c|c|}
\hline \multirow{2}{*}{ Month/Year } & \multicolumn{4}{|c|}{ Buenos Aires } & \multicolumn{4}{|c|}{ Tronco } \\
\hline & $\mathrm{pH}$ & $\begin{array}{l}\text { Temp. } \\
{ }^{\circ} \mathrm{C}\end{array}$ & Sal. & $\begin{array}{c}\mathrm{DO} \\
\mathrm{mg} \mathrm{L}^{-1}\end{array}$ & $\mathrm{pH}$ & $\begin{array}{l}\text { Temp. } \\
{ }^{\circ} \mathrm{C}\end{array}$ & Sal. & $\begin{array}{c}\mathrm{DO} \\
\mathrm{mg} \mathrm{L}^{-1}\end{array}$ \\
\hline Apr/10* & 7.1 & 29.9 & 28 & 2.5 & 7 & 30 & 25.9 & 2.7 \\
\hline Aug/10 & 7.6 & 28.6 & 35.4 & 6.8 & 7.4 & 28.8 & 31.9 & 7.4 \\
\hline 0ct/10 & 7.7 & 28.7 & 39.9 & 5.1 & 7.3 & 29.2 & 38.4 & 6.5 \\
\hline Jan $/ 11^{*}$ & 8 & 28.7 & 37.2 & 4.1 & 8 & 29.1 & 31.2 & 4.2 \\
\hline Mar/11* & 7.6 & 28.5 & 12.9 & 4.5 & 7.5 & 29.3 & 13.1 & 4.4 \\
\hline Sep/11 & 8 & 29 & 35 & 5.1 & 8 & 28.6 & 36 & 4.8 \\
\hline $\mathrm{Dec} / 11$ & 7.98 & 31.2 & 13.75 & 3.05 & 7.98 & 30.1 & 31.59 & 2.56 \\
\hline $\operatorname{Mar} / 12^{*}$ & 7.77 & 29.06 & 23.23 & 1.35 & 8.11 & 31.09 & 12.8 & 2.73 \\
\hline Jun/12 & 7.44 & 30.6 & 26.9 & 1.5 & 7.74 & 29.78 & 18.6 & 1.2 \\
\hline Mean \pm SD & $7.71 \pm 0.30$ & $29.20 \pm 0.91$ & $28.17 \pm 10.58$ & $4.06 \pm 1.71$ & $7.66 \pm 0.41$ & $29.52 \pm 0.82$ & $27.61 \pm 9.75$ & $4.41 \pm 1.79$ \\
\hline
\end{tabular}

* Represents the months with high rainfall

Table 3. Diversity and evenness of mollusc families of the epifauna and infauna found in the mangrove creeks Buenos Aires and Tronco.

\begin{tabular}{|c|c|c|c|c|c|c|}
\hline Habitat & Area & Zone & S & $\mathrm{N}$ & J' & $H^{\prime}(\log )$ \\
\hline \multirow[t]{6}{*}{ Epifauna } & Buenos Aires & 1 & 4 & 415 & 0.458 & 0.635 \\
\hline & & 2 & 4 & 413 & 0.548 & 0.76 \\
\hline & & 3 & 4 & 412 & 0.461 & 0.64 \\
\hline & Tronco & 1 & 3 & 1471 & 0.849 & 0.932 \\
\hline & & 2 & 3 & 951 & 0.516 & 0.567 \\
\hline & & 3 & 2 & 1975 & 0.034 & 0.023 \\
\hline \multirow[t]{6}{*}{ Infauna } & Buenos Aires & 1 & 5 & 6 & 0.969 & 1.561 \\
\hline & & 2 & 7 & 22 & 0.831 & 1.619 \\
\hline & & 3 & 5 & 12 & 0.897 & 1.445 \\
\hline & Tronco & 1 & 5 & 7 & 0.916 & 1.475 \\
\hline & & 2 & 4 & 22 & 0.542 & 0.751 \\
\hline & & 3 & 8 & 57 & 0.526 & 1.094 \\
\hline
\end{tabular}

For epifauna, the similarity between the creeks under study was $41.7 \%$. NMDS analysis corroborated the observation about the different distribution pattern between the creeks and the similar composition between Zones 2 and 3 (Figure 3A). It was verified by the formation of two groups defined, one for each creek at which the Zones 2 and 3 are nearest (Figure 3A). According to SIMPER analysis, the family with the highest contribution to dissimilarity between Zones 2 and 3 of the

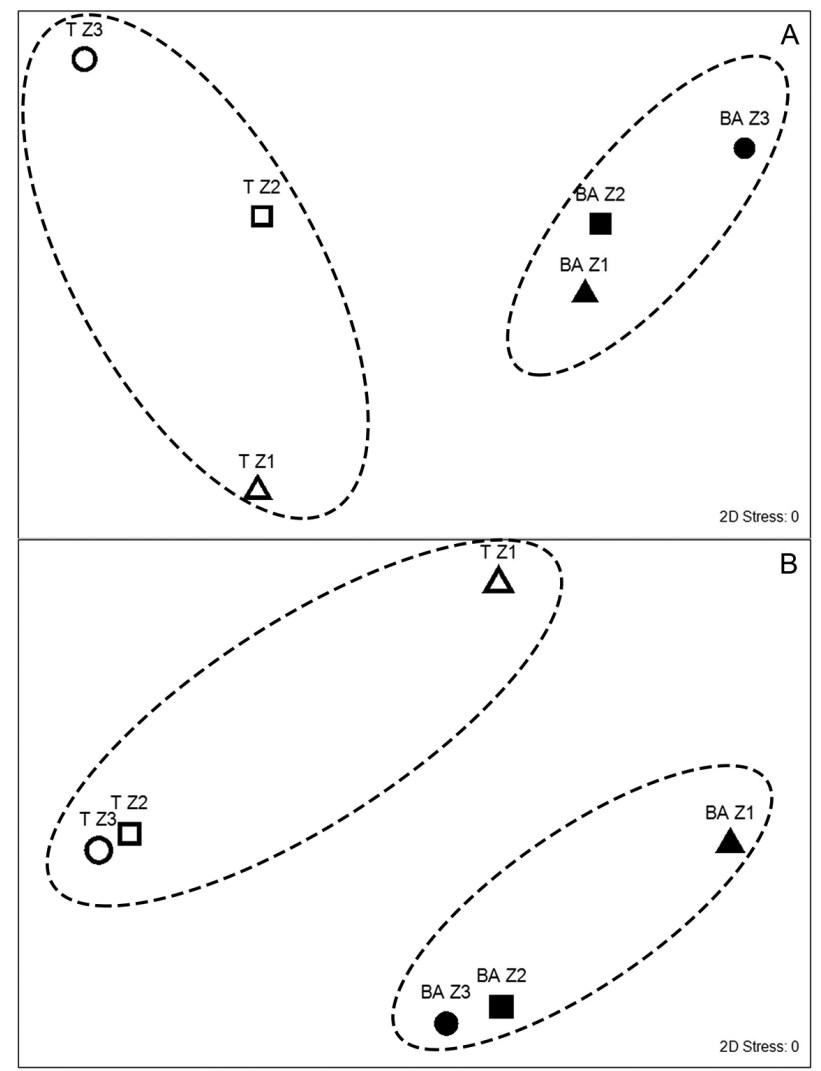

Figure 3. NMDS ordination of the studied creeks according to the abundance of molluscs based in Bray-Curtis index. (A) Epifauna. (B) Infauna. Sites: BA = Buenos Aires (filled black), $\mathrm{T}=$ Tronco (not filled). Zones: $1=\mathrm{Z1}$ (triangle), $2=\mathrm{Z2}$ (square), $3=\mathrm{Z3}$ (circle). 
Buenos Aires Creek (10.29\% dissimilarity) was Muricidae (58.15\%), and in the Tronco Creek (10.18\% dissimilarity) was Ellobiidae (81.92\%).

The mollusc distribution in the infauna showed very little similarity $(28.5 \%)$ between the creeks. Further, we were able to confirm that in both creeks, the Zones 2 and 3 were more similar than either of the zones with the Zone 1 (Figure 3B). According to the SIMPER analysis, the percentage of dissimilarity in Buenos Aires Creek was 53.50\% between Zones 2 and 3, which was the lowest, where the main contributor to the dissimilarity was Benthonella tenela (18\%). Between Zones 2 and 3 of the Tronco Creek, the dissimilarity was $20.96 \%$ and the highest contribution to the dissimilarity was from Cyrenoida sp. (22.51\%).

The sediment grain size in the Buenos Aires Creek was smaller than in the Tronco Creek. The percentage of silt/ clay $(0.96 \%)$, as well as the percentage of thin sand (2\%) in Buenos Aires Creek were very low and contributed to a greater water percentage in the saturation paste $(68.4 \%)$. The Tronco Creek exhibited $4.22 \%$ of silt/clay, $6 \%$ of thin sand, and $56.8 \%$ water in the saturation paste. The percentage of organic matter was larger in the Buenos Aires (32\%) than in the Tronco Creek (18\%).

\section{DISCUSSION}

\section{Mollusc composition}

In the epifauna, Melampus coffea was the unique species, belonging to the family Ellobiidae, the most abundant family in this study area. The rhizophores of Rhizophora mangle serve as a refuge for Melampus coffea at high tide (Maia and Tanaka 2007). In the present study, this species was observed mostly on the muddy sediment or between rhizophores of Rhizophora mangle. However, Melampus coffea was not registered for the mangrove of the Parnauaçu, Maranhão, Amazon Coast (Oliveira and Mochel 1999), which is located near the Buenos Aires Creek. Furthermore, low densities of this species were registered in the mangrove of Ajuruteua Peninsula, Pará, Amazon Coast, where higher frequencies of Littoraria angulifera and Thaisella coronata were found (Beasley et al. 2005).

Species of Littoraria were found in large quantities on leaves, roots and stems of trees, whereas Thaisella coronata was more frequently observed on dead trunks and trees, in this study. Littoraria angulifera inhabits estuarine vegetated areas (Merkt and Ellison 1998; Tanaka and Maia 2006), whereas Thaisella coronata is common in the hard bottom being found in higher density in rocky fragments from the Pará, Amazon Coast (Morais and Lee 2014).

Among the species of infauna, the abundance of Littoraria was low and Thaisella coronata did not occur. Similar results were observed in the Amazonian mangroves from Pará, Brazil by Andrade et al. (2013). Heleobia sp. was recorded only in the Buenos Aires Creek, an area rich in clay sediment. Species of this genus have been generally recorded in sandy sediments (Silva and Veitenheimer-Mendes 2004).

\section{Temporal distribution}

In this study, the molluscs were more abundant in rainiest months when the salinity was lower. Only in the month of September 2012 (dry), this pattern not observed for the infauna, which we consider a sampling stochastic event. Nevertheless, these results suggest that populations of molluscs grow seasonally following periods of heavy rainfall. In mangroves, rainfall has been considered an important factor in the distribution of benthic organisms (Hernández-Alcántara and Solís-Weiss 1995; Beasley et al. 2005).

The salinity in the creeks exhibited a strong temporal variation depending on the amount of rainfall, especially in the Buenos Aires Creek. In the benthic communities, salinity is usually one of the main factors that influence the distribution of organisms (Hedgpeth 1983; Ysebart et al. 2003). Different variation patterns of salinity can condition the diversity of molluscs owing to composition and biology of these organisms (Barroso and Matthews-Cascon 2009). Some species of molluscs show sensitivity to variations in salinity; whereas Littoraria angulifera is considered stenohaline (Ortiz and Blanco 2012), Stramonita brasiliensis has been reported to be tolerant to variations in salinity (Veiga et al. 2016).

In the rainy months, the contribution of organic matter is accumulated in the mangroves and the decomposition rates increase. The dissolved oxygen solubility in water when very low acts as a factor limiting the distribution of organisms, especially when the decomposition of organic matter demands a high microbial respiration (Goosen et al. 1999; Ysebart et al. 2003; Begon et al. 2006). Mangroves and estuaries require high levels of biological oxygen consumption, which is characteristic of standing water environments with deposits of organic matter or litter (Alongi 1990; Yesebart et al. 2003; Begon et al. 2006).

In general, at high temperatures, higher oxygen consumption is usually observed (Alongi 1990; Begon et al. 2006). Our results were different of these because the small variations in temperature did not corresponded to dissolved oxygen. Temperature could potentially be one of the main factors determining distribution of molluscs in estuaries (Rueda and Salas 2008), however, that was not the case in this study. Usually the temperature in the Maranhão State varies little and the weather is warm throughout the year.

Variations of $\mathrm{pH}$ were low for both the creeks, implying that they were not determining factors in the distribution of molluscs. This study shows low variation of $\mathrm{pH}$ with a 
mean value similar to expected values for coastal waters (Hinga 2002).

Given these characteristics of the studied mangroves, we consider that this pattern of temporal distribution contributes to resilience of the creeks, since the impact of pollution during the rainy season was reduced and the mollusc populations were better able to reproduce. This is important in terms of management and conservation.

\section{Spatial distribution}

The results of the diversity indices based on epifaunal and infaunal molluscs showed that both mangrove creeks have low diversity and richness. Estuarine communities often have low diversity, owing to the dominance of a few species usually resistant to stressful situations (Hogarth1999; Rosa-Filho et al. 2006; Aviz et al. 2012). Tropical estuarine areas typically have low number of species and high number of individuals (Dajoz 1972; Brewer 1988). These tropical species usually have ecophysiological adaptability to variations in salinity - allowing ontogenetic adaptation and influencing their distribution - to counter the effects of salinity fluctuations in the environment (Chung 2001).

The distribution of the epifaunal molluscs was different between the mangrove creeks. The Tronco Creek exhibited greater diversity and evenness. This creek is better protected than the Buenos Aires Creek, which is subject to the impacts of port activities. Degraded marine environments often show low richness and diversity (Pearson and Rosenberg 1978; Aviz et al. 2012). These two abiotic variables (particle size and organic matter) can interfere with the water flow velocity, influencing the structure of benthic communities (Petsch et al. 2013). The sediment in degraded marine areas is often characterized by high levels of organic matter and thin grain (Omena et al. 2012). The Buenos Aires Creek presented thinner sediment with high content of organic matter compared to the Tronco Creek, features that can be caused by port activity. The organic enrichment favours the establishment of tolerant species and disappearance of sensitive species causing decreased diversity (Bozelli et al. 2009). The grain size of the Tronco Creek is characterized by silt, and is similar to that in other Amazonian mangroves (e.g. Braga et al. 2011).

Both creeks showed similar patterns of distribution of molluscs along the zones. In this study, multivariate analysis has shown that the distribution of epifaunal and infaunal molluscs in the Zones 2 and 3 were very similar. The distribution of molluscs along the zones seems to follow a pattern of greater abundance and lower diversity in Zone 3 (both epifauna and infauna). The distance of tidal exposure at the infralittoral may be related to this similarity. Studies have shown that the considerable tidal variation is directly related to the dynamics of animal populations in mangroves
(Dittmann, 2000; Maia and Tanaka 2007). This strong tide oscillation contributes to the physical and chemical changes of the water circulating in the mangroves, altering the zonation pattern of the species (Borges and Silva 2013).

Zone 3 is farthest from the water line; therefore, it is more susceptible to desiccation due to shorter submergence time. The benthic fauna might follow a zonation in the intertidal area according to the different environmental conditions such as change of tide level, wave exposure, and the duration of submergence and exposure (Statzner and Higler 1986; Dittmann 2000; Koo et al. 2007). Thus, Zone 3 showed greater abundance and lower diversity owing to dominance of fewer species tolerant to desiccation. The species Melampus coffea, for example, is more tolerant to desiccation because it can breathe air through the vascularized part of the mantle cavity, which works as a lung (Russel-Hunter et al. 1972).

The initial knowledge of the spatial distribution of molluscs can serve to determinate conservation plans if a more direct impact occurs in or near the studied mangroves. This is especially true for the Buenos Aires Creek, which showed evidence of low diversity.

\section{CONCLUSIONS}

In the mangrove creeks examined in the present study, we observed a mollusc composition pattern different from other mangroves on Amazon Coast. The composition and diversity of molluscs were different between the creeks, but the same pattern of distribution along the zones was observed in the creeks. The fluctuations in environmental conditions of each mangrove creek, such salinity, dissolved oxygen, and rainfall, were found to contribute to temporal distribution of molluscs. The tidal hydrodynamics and sediment characteristics can influence the spatial distribution of benthic molluscs along the intertidal zones and between the creeks. Furthermore, we concluded that port activities might indirectly influence the patterns of mollusc distribution in the Buenos Aires Creek; therefore, we highlight the importance of management and monitoring of these areas.

\section{ACKNOWLEDGEMENTS}

We thank the Universidade Estadual do Maranhão (UEMA) for their support during the research, the MPXEnergia S.A. and Pro-Vida Brazil for the financial support given to the realization of expeditions. We are grateful to the staff of Laboratório de Pesca e Ecologia Aquática (LabPEA) for the support in the field expeditions. Special thanks to Luiz Ricardo Lopes de Simone and Daniel Caracanhas Cavallari of Museu de Zoologia da Universidade de São Paulo (MZUSP) for the help with the identification and in preparing part of the voucher specimens collected from this study. 


\section{REFERENCES}

Alongi, D.M. 1990. Effect of mangrove detrital outwelling on nutrient regeneration and oxygen fluxes in coastal sediments of the central Great Barrier Reef lagoon. Estuarine, Coastal and Shelf Science, 31: 581-598.

Alongi, D.M. 2002. Present state and future of the world's mangrove forests. Environmental Conservation, 29: 331-349.

Amaral, K.D.S.; Vieira, I.M.; Osório, F.M.; Rocha, J.D.M.; Lima, J.F. 2014. Bioecology of the crab Ucides cordatus (Crustacea, Decapoda) in mangroves influenced by the Amazon River, Brazil. Acta Amazonica, 44: 213-222.

Andrade, J.T.; Palhano, N.B.; Tagliaro, C.H.; Beasley, C.R. 2013. Spatial and temporal variation in the abundance and taxonomic composition of estuarine and terrestrial macrofauna associated with mangrove logs. Journal of the Marine Biological Association of the United Kingdom, 94: 35-42.

Aviz, D.; Rodrigues, I.L.; Rosa-Filho, J.S. 2012. Spatial and temporal changes in macrobenthic communities in the Amazon coastal zone (Guajará Estuary, Brazil) caused by discharge of urban effluents. Scientia Marina, 76: 381-390.

Ardila, N.; Navas, G.R.; Reyes, J. 2002. Libro rojo de invertebrados marinos de Colombia. 1st ed. INVEMAR, Ministerio de Medio Ambiente, Bogotá, 177p.

Barroso, C.X.; Matthews-Cascon, H. 2009. Distribuição espacial e temporal da malacofauna no estuário do rio Ceará, Ceará, Brasil. Pan-American Journal of Aquatic Sciences, 4: 79-86.

Beasley, C.R.; Fernandes, C.M.; Gomes, C.P.; Brito, B.A.; Santos, S.M.L.; Tagliaro, C.H. 2005. Molluscan diversity and abundance among coastal habitats of northern Brazil. Ecotropica, 11: 9-20.

Begon, M.; Townsend, C. R.; Harper, J. L. 2006. Ecology: from individuals to ecosystems. 4th ed. Blackwell Publishing, Oxford, 745p.

Borges, A.C.; Silva, V.M. 2013. Influência hidrogeoquímica da água subterrânea em manguezais. Geochimica Brasiliensis, 27: 98-103.

Bozelli, R.L.; Caliman, A.; Guariento, R.D.; Carneiro, L.S.; Santangelo, J.M.; Figueiredo-Barros, M.P.; et al. 2009. Interactive effects of environmental variability and human impacts on the long-term dynamics of an Amazonian floodplain lake and a South Atlantic coastal lagoon. Limnologica, 39: 306-313.

Braga, C.F.; Monteiro, V.F.; Rosa-Filho, J.S.; Beasley, C.R. 2011. Benthic macroinfaunal assemblages associated with Amazonian saltmarshes. Wetlands Ecology and Management, 19: 257-272.

Brewer, R. 1988. The science of ecology. Philadelphia, Saunders College Publishing Co. 922p.

Chung, K.S. 2001. Adaptabilidad ecofisiológica de organismos acuáticos tropicales a cambios de salinidad. Revista de Biologia Tropical, 49: $9-13$.

Clarke, K.R.; Gorley, R.N. 2006. PRIMER v6: User manualltutorial. PRIMER-E. Plymouth, 192p.

Clarke, K.R.; Warwick, R.M. 2001. Change in marine communities: an approach to statistical analysis and interpretation. Natural Environment Research Council, UK, 172p.
Correia, M.D.; Sovierzoski, H.H. 2005. Ecossistemas Marinhos: recifes, praias e manguezais. Maceió, EDUFAL. 55p.

Dajoz, R. 1972. Ecologia geral. São Paulo, EDUSP. 474p.

Dittmann, S.2000. Zonation of benthic communities in a tropical tidal flat of north-east Australia. Journal of Sea Research, 43: 33-51.

Floeter, S.R.; Gasparini, J. L. 2000. The southwestern atlantic reef fish fauna: composition and zoogeographic patterns. Journal of Fish Biology, 56, 1099-1114

Gazeau, F.; Parker, L.M.; Comeau, S.; Gattuso, J.P.; O’Connor, W.A.; Martin, S.; Pörtner, H.O.; Ross, P.M. 2013. Impacts of ocean acidification on marine shelled molluscs. Marine Biology, 160: 2207-2245.

Gomes, J.D.; Abrunhosa, F.A.; Simith, D.J.B.; Asp, N.E. 2013. Mangrove sedimentary characteristics and implications for crab Ucides cordatus (Crustacea, Decapoda, Ucididae) distribution in an estuarine area of the Amazonian region. Acta Amazonica, 43: 481-488.

Greenfield, D.W. 1989. Priolepis dawsoni n. sp. (Pisces: Gobiidae), a third Atlantic species of Priolepis. Copeia, 1989: 397-401.

Goosen, N.K.; Kromkamp, J.; Peene, J.; Rijswijk, P.; Breugel, P. (1999). Bacterial and phytoplankton production in the maximum turbidity zone of three European estuaries: the Elbe, Westerschelde and Gironde. Journal of Marine Systems, 22: 151-171.

Hall, S.J. 1994. Physical disturbance and marine benthic communities: Life in unconsolidated sediments. Oceanography and Marine Biology: an Annual Review, 32: 179-239.

Hedgpeth, J.W. 1983. Coastal Ecosystems, Brackish Waters, Estuaries, and Lagoons. In: Kinne, O. (Ed.). Marine Ecology. v. 5. Wiley, Chichester, p. 739-757.

Hemández-Alcántara, P.; Solis-Weiss, V. 1995. Algunas comunidades macrobénticas asociadas al manglar (Rhizophora mangle) en laguna de Términos, Golfo de México. International Journal of Tropical Biology and Conservation, 43: 117-129.

Hinga, K.R. 2002. Effects of $\mathrm{pH}$ on coastal marine phytoplankton. Marine Ecology Progress Series 238: 281-300.

Hogarth, P.J. 1999. The biology of mangroves. Oxford: Oxford University Press, 228p.

Koo, B.J., Kwon, K.K.; Hyun, J.H. 2007. Effect of environmental conditions on variation in the sediment-water interface created by complex macrofaunal burrows on a tidal flat. Journal of Sea Research, 58: 302-312.

Maia, R.C.; Tanaka, M. O. 2007. Avaliação de efeitos de espécies de mangue na distribuição de Melampus coffeus (Gastropoda, Ellobiidae) no Ceará, nordeste do Brasil. Iheringia. Série Zoologia, 97: 379-382.

Marquéz, B.; Jimenéz, M. 2002. Moluscos associados a las raíces sumergidas del mangle rojo Rhizophora mangle, en el Golfo de Santa Fe, Estado Sucre, Venezuela. Revista Biologia Tropical, 50: 1101-1112.

Melo, K.R.; Tagliaro, C.H.; Beasley, C.R. 2013. Seasonal changes in the subtidal benthic macrofauna of a mangrove coast in northern Brazil. Journal of Coastal Research, Special Issue 65: 87-91. 
Menezes, M.P.M.D.; Berger, U.; Mehlig, U. 2008. Mangrove vegetation in Amazonia: a review of studies from the coast of Pará and Maranhão States, north Brazil. Acta Amazonica, 38: 403-420.

Luiz, O.J.; Madin, J.S.; Robertson, D.S.; Rocha, L.A.; Wirtz, P.; Floeter, S.R. 2012. Ecological traits influencing range expansion across large oceanic dispersal barriers: insights from tropical Atlantic reef fishes. Proceedings of the Royal Society, 279: 1033-1040.

Merkt, R.E.; Ellison, A.M. 1998. Geographic and habitat-specific morphological variation of Littoraria (Littorinopsis) angulifera (Lamarck, 1822). Malacologia, 40: 279-295.

Mochel, F.R. 1986. Metodologia para estudo da endofauna de manguezais (macrobenthos). Caribbean Ecological Research, 1: 1-25.

Morais, G.C.; Lee, J.T. 2014. Intertidal benthic macrofuna of rare rocky fragments in the Amazon region. Revista de Biología Tropical, 62: 69-86.

Núcleo Geoambiental, 2012. Temperatura mínima (http://www.nugeo. uema.br/?page id=88). Accessed on 17/05/2015.

Odum, E.P.; Barrett, G. W. 2007. Fundamentos de Ecologia. 5th ed. São Paulo, Thomson Learning. 612p.

Oliveira, V.M.; Mochel, F.R. 1999. Macrofauna bentônica de substratos móveis de um manguezal sob impacto das atividades humanas no sudoeste da Ilha de São Luís, Maranhão, Brasil. Boletim do Laboratório de Hidrobiologia, 12: 75-93.

Omena, E.P.; Lavrado, H.P.; Paranhos, R.; Silva, T.A. 2012. Spatial distribution of intertidal sandy beach polychaeta along an estuarine and morphodynamic gradient in an eutrophic tropical bay. Marine Pollution Bulletin, 64: 1861- 1873.

Ortiz, L.F.; Blanco, J.F. 2012. Distribución de los gasterópodos del manglar, Neritina virginea (Neritidae) y Littoraria angulifera (Littorinidae) en la Ecorregión Darién, Caribe colombiano. Revista de Biología Tropical, 60: 219-232.

Pearson, T.H.; Rosenberg, R. 1978. Macrobenthic succession in relation to organic enrichment and pollution of the marine environment. Oceanography and Marine Biology: An Annual Review, 16: 229-311.

Pereira, J.E.R.; Harari, J. 1995. Modelo numérico tri-dimensional linear da plataforma continental do Estado do Maranhão. Boletim do Instituto Oceanográfico, 43: 11-26.

Peterson, C.H., 1991. Intertidal zonation of marine invertebrates in sand and mud. American Scientist, 79: 236-249.

Petsch, D.K.; Pinha, G.D.; Ragonha, F. H.; Takeda, A.M. 2013. Influência dos fatores ambientais sobre a distribuição da comunidade de invertebrados bentônicos em canais de uma planície de inundação neotropical. Biotemas, 26: 127-138.

Rezende, R.S.; Santos, A.M.; Henke-Oliveira, C.; Gonçalves Jr, J.F. 2014. Effects of spatial and environmental factors on benthic a macroinvertebrate community. Zoologia (Curitiba), 31: 426-434.

Ribeiro, R.P.; Almeida, Z.S. 2014. Anelídeos poliquetas do estado do Maranhão, Brasil: síntese do conhecimento. Bioikos, 28: 45-55.

Rosa Filho, J. S.; Busman, D. V.; Viana, A. P.; Gregório, A. M.; Oliveira, D. M. 2006. Macrofauna bentônica de zonas entre-marés não vegetadas do estuário do rio Caeté, Bragança, Pará. Boletim do Museu Paraense Emílio Goeldi Ciências Naturais, 1: 85-96.
Rueda, J. L.; Salas, C. 2008. Molluscs associated with a subtidal Zostera marina L. bed in southern Spain: linking seasonal changes of fauna and environmental variables. Estuarine, Coastal and Shelf Science, 79: 157-167.

Russel-Hunter, W.D.; Apley, M.L.; Hunter, R.D. 1972. Early-life-history of Melampus and the significance of semilunar synchrony. Biology Bulletin, 143: 625-656.

Santi, L.; Tavares, M. 2009. Polychaete assemblage of na impacted estuary, Guanabara Bay, Rio de Janeiro, Brazil. Brazilian Journal of Oceanography, 57: 287-303.

Silva, M.C. P.; Veitenheimer-Mendes, I.L. 2004. Nova espécie de Heleobia (Rissooidea, Hydrobiidae) da planície costeira do sul do Brasil. Iheringia, Série Zoologia, 94: 89-94.

Silva, I.R.; Pereira, L.C.C.; Guimarães, D.O.; Trindade, W.N.; Asp, N.E.; Costa, R.M. 2009. Environmental status of urban beaches in São Luís (Amazon Coast, Brazil). Journal of Coastal Research, 56: $1301-1305$.

Soares-Gomes, A.; Pires-Vanin, A.M.S. 2003. Padrôes de abundância, riqueza e diversidade de moluscos bivalves na plataforma continental ao largo de Ubatuba, São Paulo, Brasil: uma comparação metodológica. Revista Brasileira de Zoologia, 20: 717-725.

Sousa, D.B.; Santos, N.B.; Oliveira, V.M.; Carvalho-Neta, R.N.F.; Almeida, Z.S. 2015. Carcinofauna bêntica estuarina de dois manguezais da costa amazônica maranhense, Brasil. Iheringia. Série Zoologia, 105: 339-347.

Souza-Filho, P.W.M.S. 2005. Costa de manguezais de macromaré da Amazônia: cenários morfológicos, mapeamento e quantificação de áreas usando dados de sensores remotos. Revista Brasileira de Geofisica, 23: 427-435.

Spalding, M.; Blasco, F.; Field, C.D. 1997. World mangrove atlas. Okinawa, The international Society for Mangrove Ecosystems. 178p.

Statzner, B.; Higler, B. 1986. Stream hydraulics as a major determinant of benthic invertebrate zonation patterns. Freshwater Biology, 16: 127-139.

Tagliapietra, D.; Sigovini, M. 2010. Benthic fauna: collection and identification of macrobenthic invertebrates. Terre et Environnement, 88: 253-261.

Tanaka, M.O.; Maia, R.C. 2006. Shell morphological variation of Littoraria angulifera among and within mangroves in NE Brazil. Hydrobiologia, 559: 193-202.

Veiga, M.P.T.; Gutierre, S.M.; Castellano, G.C.; Freire, C.A. 2016. Tolerance of high and low salinity in the intertidal gastropod Stramonita brasiliensis (Muricidae): behaviour and maintenance of tissue water content. Journal of Molluscan Studies, 82: 154-160.

Ysebart, T.; Herman, P.M.J.; Meire, P.; Craeymeersch, J.; Verbeek, H.; Heip, C.H.R. 2003. Large-scale spatial patterns in estuaries: estuarine macrobenthic communities in the Schelde estuary, NW Europe. Estuarine, Coastal and Shelf Science, 57: 335-355.

Recebido em 02/03/2016

Aceito em 13/06/2016 